\title{
Perkembangan Madrasah Aliyah Negeri Palopo, 1990-2007
}

\author{
Hapsari, Muh. Rasyid Ridha, Bustan \\ Prodi Pendidikan Sejarah Fakultas Ilmu Sosial Universitas Negeri Makassar \\ hapsarihapsa23@gmail.com
}

\begin{abstract}
Abstrak
Penelitian ini bertujuan untuk mengetahui proses peralihan PGAN ke MAN Palopo, perkembangan MAN Palopo dalam kurun waktu tahun 1990-2007, serta peran MAN Palopo dalam bidang pendidikan dan keagamaan dan bidang sosial. Hasil penelitian ini menunjukkan bahwa peralihan dari PGAN menjadi MAN melalui beberapa tahap yaitu mulai dari PGAN 4 tahun kemudian masa belajarnya ditambah 2 tahun menjadi PGAN 6 tahun kemudian menjadi MTs dan akhirnya menjadi MAN. Seiring berjalannya waktu setelah mengalami peralihan MAN Palopo ini juga mengalami perkembangan dari segala aspek, baik dari sisi akademik maupun non akademik serta dari segi perkembangan fisik maupun non fisik madrasah. MAN Palopo ini memiliki peran yang sangat penting bagi masyarakat setempat, misalnya dalam bidang pendidikan dan keagamaan yaitu penanaman akhlakul karimah, media sosialisasi keislaman dan benteng moralitas peserta didik dan juga dalam bidang sosial yaitu sebagai wadah untuk beradaptasi dengan masyarakat setempat. Penelitian ini menyimpulkan bahwa MAN Palopo yang didirikan pada tahun 1990 mengalami perkembangan yang cukup pesat yang dibuktikan dengan adanya perbaikan dan penambahan fasilitas di sekolah serta prestasi akademik maupun non akademik. Penelitian ini menggunakan metode penelitian sejarah yang terdiri atas empat tahapan yaitu : heuristik (pengumpulan data atau sumber), kritik sumber yang terdiri dari kritik intern dan ekstern, interpretasi atau penafsiran sumber dan historiografi yaitu penulisan sejarah
\end{abstract}

Kata Kunci : Madrasah Aliyah, Palopo

\begin{abstract}
This study aims to determine the process of transition from PGAN to MAN Palopo, the development of MAN Palopo in the period 1990-2007, and the role of MAN Palopo in the fields of education and religion and the social field. The results of this study indicate that the transition from PGAN to MAN through several stages, starting from PGAN 4 years later, the study period was added 2 years to PGAN 6 years later to become MTs and finally became MAN. Over time after undergoing the transition MAN Palopo is also experiencing growth in all aspects, both in terms of academic and non-academic as well as in terms of physical and non-physical development of madrasas. This Palopo MAN has a very important role for the local community, for example in the field of education and religion, namely the cultivation of morality, the Islamic media and the morality of students' morality and also in the social field as a forum to adapt to the local community. This study concludes that MAN Palopo, which was established in 1990, has experienced quite rapid development as evidenced by the improvement and addition of facilities in schools as well as academic and non-academic achievements. This study uses a historical research method which consists of four stages, namely: heuristics (collecting data or sources), source criticism consisting of internal and
\end{abstract}

Vol. 6, No.2 Agustus 2019, 123-131 | 123 
external criticism, interpretation or interpretation of sources and historiography, namely writing history

\section{Key words: Madrasah Aliyah, Palopo}

\section{A. Pendahuluan}

Madrasah sebagai lembaga pendidikan Islam yang bersifat formal telah berkembang dalam kehidupan masyarakat. Secara umum madrasah juga sama dengan sekolah-sekolah lain, yaitu lembaga pendidikan yang menggunakan sistem klasikal dan kelas dengan segala fasilitasnya seperti kursi, meja dan papan tulis, kecuali aspek tradisi dan kurikulum yang dilaksanakan. (Susanti, n.d.) Sekolah ini merupakan institusi pendidikan yang berada di bawah naungan Kementrian Agama. Berbagai langkah kebijaksanaan pendidikan dalam peningkatan mutu madrasah telah dilakukan. Langkah pertama Kementrian Agama dalam melakukan pembinaan terhadap keberadaan madrasah adalah memberikan bantuan berupa pengadaan sarana dan prasarana serta biaya operasional, sebagaimana tertuang dalam Peraturan Menteri Agama Nomor 1/1946, tanggal 19 Desember 1946. (Kosim, 2007)

Pendidikan Islam di Sulawesi Selatan awalnya berupa pesantren yang pada dasarnya hampir sama dengan sistem pengajaran Islam di daerah Jawa. Namun seiring perkembangan zaman, maka pendidikan mulai dilembagakan dengan didirikannya madrasah-madrasah. Madrasah berasal dari Bahasa Arab: darasa, yadrusu, darsan, yang berarti tempat belajar. (Nata, 2012)

Maraknya perkembangan madrasah di Sulawesi Selatan, di Palopo juga telah berdiri madrasah yaitu Madrasah Aliyah Negeri Palopo. Madrasah Aliyah Negeri atau disingkat MAN Palopo ini adalah alih fungsi dari PGAN (Pendidikan Guru Agama Negeri) Palopo. PGAN Palopo awal mulanya didirikan pada tahun 1960, yang namanya adalah PGAN 4 Tahun (setingkat SLTP), kemudian masa belajarnya ditambah 2 tahun menjadi PGAN 6 Tahun (setingkat SLTA). Hal itu berlangsung dari tahun 1968 sampai dengan 1986. Kemudian pada tahun 1986 masa belajarnya berubah menjadi tiga tahun setelah mengalami perubahan dari PGAN 4 Tahun yang setingkat dengan Sekolah Pendidikan Guru (SPG) pada waktu itu menjadi MTs. Dua tahun menjelang masa belajar PGAN Palopo berakhir, yaitu pada tahun 1990 dialihfungsikan menjadi Madrasah Aliyah Negeri atau MAN Palopo. Hal itu didasarkan pada Surat Keputusan Menteri Agama RI, Nomor 64 tahun 1990 pada tanggal 25 April 1990.

Keberadaan madrasah merupakan tonggak baru dalam penyelenggaraan pendidikan Islam yang banyak memberikan kontribusi terhadap perkembangan dunia pendidikan pada masa-masa berikutnya. (Kosim, 2007) Karenanya, kiprah madrasah tidak dapat dipandang sebelah mata karena madrasah memiliki peran penting dalam pendidikan pendidikan nasional secara bersama membangun pendidikan ke arah yang lebih baik demi terwujudnya bangsa yang cerdas dan berakhlak mulia dengan mengedepankan nilai-nilai agama sebagai pegangan dalam kehidupan. (Alawiyah , 2014)

Beberapa penelitian sebelumnya seputar Madrasah telah menghasilkan beberapa karya ilmiah jurnal yang menjelaskan mengenai perkembangan madrasah seperti yang ditulis oleh Mohammad Kosim pada tahun 2007 dengan judul Madrasah di Indonesia (Pertumbuhan dan Perkembangan) yang menjelaskan mengenai asal usul dan latar belakang perkembangannya terutama terkait dengan kebijakan-kebijakan politik pemerintah terhadap keberadaan madrasah.

Perbandingan pada penelitian lainnya adalah skripsi karya Jalwiah tahun 2001 yang berjudul Madrasah Aliyah Negeri 1 
Makassar yang menjelaskan bagaimana MAN I Makassar dalam perkembangan pendidikan di kota Makassar dalam rentang waktu tahun 1981-2001.

Sehingga dari kedua sumber relevan tersebut, maka fokus kajian pada penelitian ini adalah kehadiran MAN Palopo dengan perkembangannya serta berusaha mengkaji secara spesifik peran dari MAN Palopo sebagai satu-satunya MAN yang ada di kota Palopo itu sendiri.

\section{B. Metode Penelitian}

Penelitian ini menggunakan metode penelitian sejarah yang terdiri dari empat tahap, yaitu heuristik (mencari dan mengumpulkan sumber). Penulis melakukan wawancara terhadap beberapa guru di Madrasah Aliyah Palopo seperti Bapak Haeruddin dan Bustam. Adapun bahan-bahan pustaka penulis diperoleh dari sejumlah perpustakaan, sepertii Perpustakaan Sejarah FIS-UNM, Perpustakaan Daerah Kota Palopo, dan Perpustakaan IAIN Palopo. Selanjutnya, penulis melakukan kritik baik kritik ekstern dan kritik intern, interpretasi (penafsiran sumber) dan historiografi (penulisan sejarah). Metode pengumpulan data dilakukan dengan cara melakukan penelitian lapangan (wawancara, pengamatan dan penelitian pustaka.

\section{Tinjauan Umum Pendidikan Islam di Kota Palopo}

1. Pendidikan Islam Di Kota Palopo

Pendidikan Islam di Kota Palopo sudah berlangsung cukup lama. Pendidikan Islam dapat dikatakan sudah berlangsung sejak masuknya Islam ke wilayah ini. Sejak masuknya Islam di wilayah ini dan dijadikan sebagai agama kerajaan maka orang-orang mengikuti seruan raja untuk masuk ke dalam agama Islam. Pada masa kerajaan, adanya kegiatan pendidikan Islam di Kota Palopo tergantung bagaimana perhatian yang diberikan oleh kerajaan. Dapat dilihat bahwa memang pendidikan Islam memperoleh dukungan yang cukup baik dari para raja. Hal tersebut dibuktikan dengan adanya ajakan dan seruan dari raja untuk mengikutinya.

Situasi dan kondisi pendidikan Islam di Kota Palopo pada tahun 1960-an hanya berupa pendidikan PGAN 4 tahun yang kemudian berganti menjadi PGAN 6 tahun dan kemudian dilebur menjadi Madrasah Tsanawiyah Negeri. Namun, pada tahun 1990-an kemudian ada yang dialihfungsikan menjadi Madrasah Aliyah Negeri yang setingkat dengan sekolah menengah atas. Hal tersebut dapat membantu masyarakat untuk melanjutkan putra-putrinya ke lembaga pendidikan yang bercorak Islam.

2. Balandai Sebagai Wilayah Madrasah Aliyah Negeri Palopo

Madrasah Aliyah Negeri Palopo terletak di Kelurahan Balandai, Kecamatan Bara, Kota Palopo. Balandai dimekarkan pada bulan Mei 2006 dengan nama Kelurahan Balandai, Kecamatan Bara, Kota Palopo dengan status tanah hak milik dan sudah bangunan sendiri. Batas-batas administrative kelurahan Balandai yakni, sebelah Selatan berbatasan dengan Kelurahan Salobulo, Kecamatan Wara. Sebelah Utara berbatasan Kelurahan Temmalebba, Kecamatan Bara. Sebelah Barat berbatasan dengan Kelurahan Battang Kecamatan Wara Barat. Sebelah Timur berbatasan dengan Teuk Bone

Kelurahan Balandai ini memiliki luas wilayah $5,6 \mathrm{~km}^{2}$ yang terdiri dari daratan, pegunungan dan pantai. Kelurahan Balandai memiliki $5 \mathrm{RW}$ dan 17 RT. Jumlah penduduknya \pm 5.057 jiwa dan ada \pm 1.033 kepala keluarga. Jarak dari ibu kota kecamatan $\pm 0,5 \mathrm{~km}$, jarak dari ibu kota kabupaten/kota $\pm 4 \mathrm{~km}$ dan jarak dari ibu kota provinsi $\pm 386 \mathrm{~km}$.

\section{Pembahasan}

\section{Proses Peralihan PGAN Menjadi} Madrasah Aliyah Negeri Palopo

Madrasah Aliyah Negeri Palopo merupakan institusi pendidikan yang berada di bawah naungan Kementerian Agama yang awalnya bernama PGAN 4 tahun yang kemudian sampai sekarang 
PATTINGALLOANG

(C) Pemikiran Pendidikan dan Penelitian Kesejarahan

dikenal dengan MAN Palopo. PGAN (Pendidikan Guru Agama Negeri) Palopo awal mulanya didirikan pada tahun 1960, yang namanya adalah PGAN 4 Tahun (setingkat dengan SLTP), kemudian masa belajarnya ditambah 2 tahun menjadi PGAN 6 Tahun (Setingkat dengan SLTA). Hal tersebut berlangsung dari tahun 1968 sampai dengan tahun 1986. Kemudian pada tahun 1986 sampai dengan tahun 1993 masa belajarnya berubah menjadi tiga tahun setelah mengalami perubahan dari PGAN 4 Tahun yang setingkat dengan SPG (Sekolah Pendidikan Guru) saat itu menjadi MTs (Madrasah Tsanawiyah). Masa belajar tiga tahun tersebut berakhir pada tahun 1993. Namun dua tahun menjelang masa belajarnya berakhir, yaitu pada tahun 1990 dialihfungsikan menjadi Madrasah Aliyah Negeri atau MAN Palopo. Hal itu didasarkan pada Surat Keputusan Menteri Agama RI, nomor 64 Tahun 1990 pada tanggal 25 April 1990. (Hawa, 2019)

\section{Berdirinya Madrasah Aliyah Negeri Palopo}

Sekolah ini berdiri sebagai bentuk alihfungsi dari PGAN Palopo melalui beberapa tahapan pada tahun 1990 berdasarkan Surat Keputusan Menteri Agama RI, Nomor 64 Tahun 1990 pada tanggal 25 April 1990. Pada saat itu pula Madrasah Aliyah Negeri Palopo sebagai salah satu lembaga pendidikan formal yang dikelolah oleh Departemen Agama mulai dikembangkan sejalan dengan kebutuhan dan tuntutan masyarakat yang ada di Kota Palopo. Selama rentang waktu dari tahun 1990 sampai akhir tahun 2007, dari PGAN Palopo lalu beralih fungsi menjadi MAN Palopo, telah mengalami beberapa kali pergantian Kepala Sekolah yang bisa dilihat pada tabel berikut

Tabel 1. Nama Pimpinan PGAN/MAN Palopo

\begin{tabular}{|l|l|c|}
\hline No. & \multicolumn{1}{|c|}{ Kepala Sekolah } & Periode \\
\hline 1. & H. Abdul Latif P, B.A & $1990-1996$ \\
\hline 2. & Drs. M. Jahja Hamid & $1996-2001$ \\
\hline
\end{tabular}

\begin{tabular}{|l|l|l|}
\hline 3. & Drs. Somba & $2001-2003$ \\
\hline 4. & $\begin{array}{l}\text { Drs. H. Mustafa } \\
\text { Abdullah }\end{array}$ & $2003-2005$ \\
\hline 5. & Nusjam Baso, S.Pd & $2005-2007$ \\
\hline
\end{tabular}

Sumber Data : Staf TU Madrasah Aliyah Negeri (MAN) Palopo

Dapat dilihat pada tabel di atas bahwa telah terjadi lima kali pergantian pemimpin pada Madrasah Aliyah Negeri Palopo dengan rata-rata waktu menjabat sekitar dua tahun dan paling lama sekitar lima tahun. Masa jabatan terlama terjadi pada masa kepemimpinan Bapak H. Abdul Latif P, BA dan Bapak Drs. M. Jahja Hamid.

a. Visi, Misi, dan Tujuan Madrasah Aliyah

Negeri Palopo

Visi, misi dan tujuan tersebut sejalan dengan kinerja para pendidik yang ada di Madrasah Aliyah Negeri Palopo yang dapat dilihat dengan adanya peserta didik yang meraih prestasi pada kegiatan akademik seperti lomba OSN dan juga dapat dilihat dari peserta didik yang dengan segera melaksanakan shalat ketika telah masuk waktu shalat. Dapat pula dilihat pada bulan Ramadhan yang diimplementasikan dengan ikutnya peserta didik untuk berdakwah di masjid-masjid.

b. Sarana dan Prasarana

Sarana dan prasarana yang ada di Madrasah Aliyah Negeri Palopo sudah cukup memadai. Fasilitas yang baik dapat menunjang proses belajar mengajar untuk lebih baik lagi. Adanya sarana dan prasarana di atas juga mampu membantu Madrasah Aliyah Negeri Palopo untuk mencapai tujuan pendidikan yang maksimal. Sarana dan prasarana tersebut diperadakan dengan menggunakan dana yang berasal dari pemerintah berupa dana rutin DIPA, BOS dan BOSDA.

c. Peserta didik

Keadaan peserta didik Madrasah Aliyah Negeri Palopo dari tahun ke tahun 
PATTINGALLOANG

(C) Pemikiran Pendidikan dan Penelitian Kesejarahan

Sumber Data: Kesiswaan Madrasah Aliyah Negeri (MAN) Palopo

Berdasarkan tabel di atas dapat diketahui bahwa jumlah peserta didik di Madrasah Aliyah Negeri Palopo dari tahun ke tahun mengalami pasang surut seperti pada tahun 2010 hingga tahun 2014. Namun pada tahun 2015 sampai sekarang kemudian kembali mengalami perkembangan dengan bertambahnya jumlah peserta didik dari tiga ratusan menjadi empat ratusan bahkan sampai enam ratusan.

d. Guru/Tenaga Pendidik

Keadaan Tenaga Pendidik/Guru Di Madrasah Aliyah Negeri (MAN) Palopo

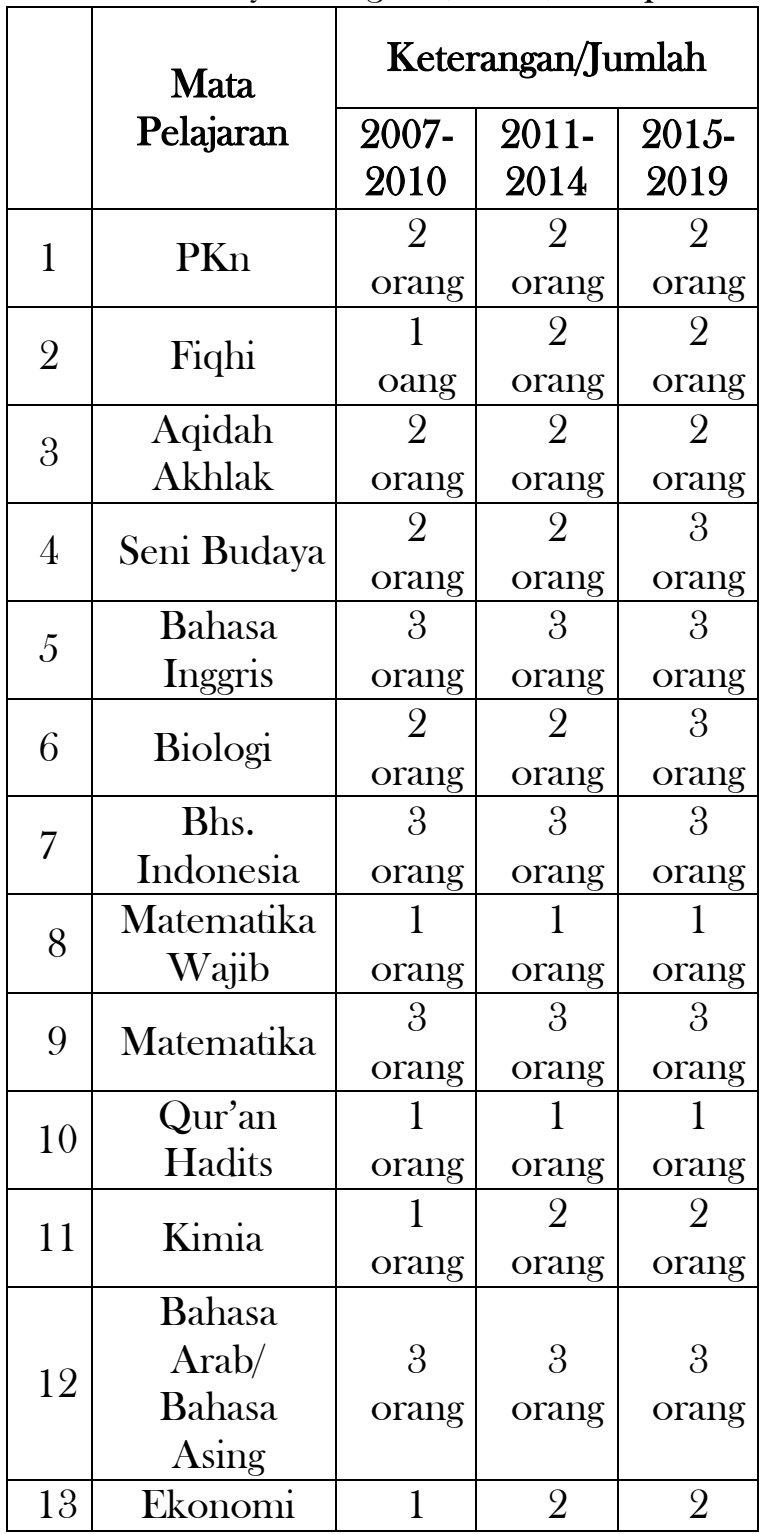

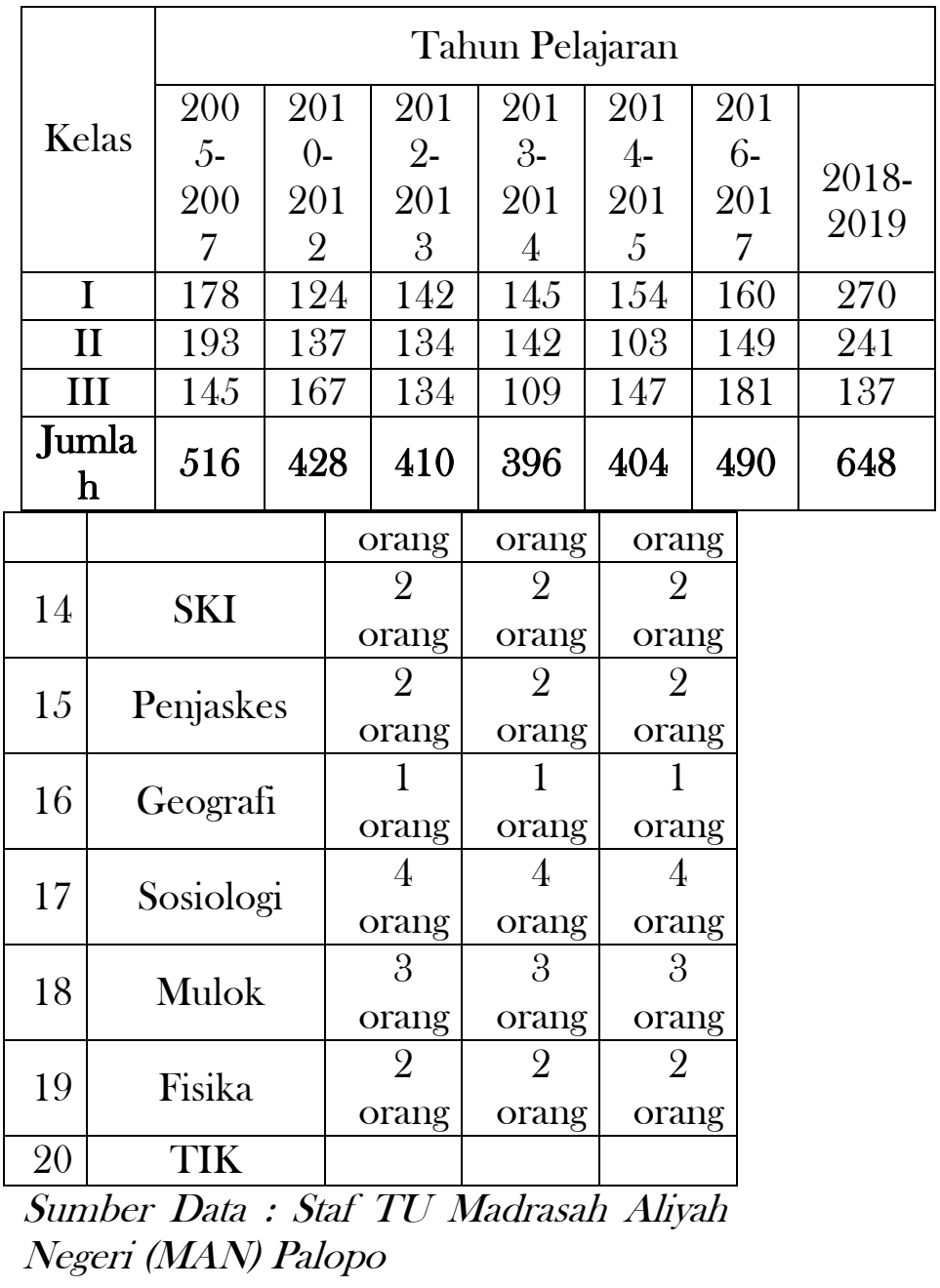

Berdasarkan tabel di atas dapat dikatakan bahwa keadaan tenaga pendidik yang ada di Madrasah Aliyah Negeri Palopo sudah cukup memadai. Tenaga pendidik yang ada juga sudah sebanding dengan mata pelajaran yang ada. Tabel di atas menunjukkan bahwa ada sekitar 46 tenaga pendidik dengan jumlah mata pelajaran sebanyak 20. Kebanyakan dari guru-guru tersebut merupakan Alumni dari PGAN atau Madrasah Aliyah Negeri Palopo itu sendiri.

e. Kurikulum

Dalam menjalankan proses belajar mengajar di Madrasah Aliyah Negeri Palopo, maka kurikulum yang digunakan berpedoman pada kurikulum Departemen Agama untuk mata pelajaran : Al-Qur'an dan Hadist, Aqidah Akhlak, Bahasa Arab, Fiqh dan Sejarah Kebudayaa Islam. 
Adapun untuk mata pelajaran umum berpedoman pada kurikulum Dinas Pendidikan Nasional yaitu mata pelajaran umum seperti : Kewarganegaraan, Bahasa Indonesia, Bahasa Inggris, Matematika, Fisika, Kimia, Biologi, Ekonomi, Sosiologi, Sejarah Nasional dan Umum, Geografi, Pendidikan Jasmani, Olahraga dan Kesehatan, Teknologi Informasi dan Telekomunikasi, dan Pendidikan seni budaya.

\section{Perkembangan Madrasah Aliyah Negeri Palopo pada Tahun 1990-2007 \\ a. Madrasah Aliyah Negeri Palopo Tahun 1990-2001 \\ Pada tahun 1990-2001 Madrasah} Aliyah Negeri Palopo dipimpin oleh dua orang kepala sekolah. Kepala sekolah yang pertama yakni Bapak Drs. Abd. Layif P, BA yang menjabat dari tahun 1990-1996 dan kemudian setelahnya digantikan oleh Bapak Drs. Jahja Hamid dari tahun 19962001.

Perkembangan dan kemajuan yang dialami oleh Madrasah Aliyah Negeri Palopo pada masa ini adalah tercpitanya suasana belajar yang baik, meningkatnya kesejahteraan guru, dan terjalin keharmonisan di antara guru dan peserta didik serta proses belajar mengajar berjalan dengan lancar. Proses belajar mengajar yang baik inilah yang dapat memberikan hal-hal menggembirakan bagi Madrasah Aliyah Negeri Palopo seperti adanya prsetasiprestasi yang diraih oleh peserta didik baik dari segi akademik maupun non akademik.

b. Madrasah Aliyah Negeri Palopo pada

Tahun 2001-2007

Rentang waktu selama enam tahun ini Madrasah Aliyah Negeri Palopo mengalami pergantian pemimpin sebanyak tiga kali. Pada tahun 2001-2003 dipimpin oleh Bapak Drs. Somba yang kemudian digantikan oleh Bapak Drs. H. Mustafa Abdullah pada tahun 2003-2005. Kemudian pada tahun 2005 setelah masa kepemimpinan Bapak Drs. H. Mustafa Abdullah berakhir, beliau digantikan oleh
Bapak Nursjam Baso, S. Pd hingga tahun 2007.

Perkembangan yang terlihat pada masa ini yakni banyak mengukir prestasi dari segi non akademik seperti pada kegiatan ekstrakurikuler. Peserta didik di Madrasah Aliyah Negeri Palopo sering menjuarai lomba kegiatan pramuka antar sekolah. Dalam bidang keagamaan juga peserta didiknya biasa menjuarai lomba tilawatil qur'an. Seperti yang dikemukakan oleh Ibu Dra. Maida Hawa, M.Pd:

"Prestasi-prestasi yang diraih oleh Madrasah Aliyah Negeri Palopo selama ini bukan hanya dari segi akademik saja tetapi juga ada dari segi ekstrakurikuler seperti kegiatan lomba pramuka dan juga lomba-lomba di bidang keagamaan". (Hawa, 2019)

Perkembangan lain yang dapat dilihat pada masa kepemimpinan Bapak Drs. Mustafa Abdullah adalah jumlah peserta didik yang masuk di Madrasah Aliyah Negeri Palopo yang sedikit demi sedikit mengalami peningkatan dan juga mencetak peserta didik yang memang itulah yang ditunggu-tunggu oleh masyarakat yang ada di luar. Seperti yang dikatakan oleh Bapak M. Bustam T, M.Pd. I bahwa:

"Periode Bapak Drs. Mustafa Abdullah selama menjabat sebagai kepala sekolah memang sangat singkat, namun pada masanya terlihat perkembangan yang cukup memuaskan. Pada masanya, jumlah peserta didik berangsur-angsur mulai meningkat dan presatsi yang dicapai juga tidak kendor. Selain itu, Madrasah Aliyah Negeri Palopo pada masa ini mencetak peserta didik yang keluarannya memang sudah ditunggu-tunggu oleh masyarakat dan tidak

Vol. 6, No.2 Agustus 2019, 123-131 | 128 
mengecewakan masyarakat yang ada di luar". (Bustam, 2019)

Satu lagi perkembangan yang dapat dilihat pada masa ini yaitu dari segi sarana dan prasarana yang banyak mengalami perbaikan dan peningkatan. Pengembangan sarana dan prasarana yang dilakukan di Madrasah Aliyah Negeri Palopo berupa perangkat keras, semisal pengadaan pembangunan sarana dan prasarana yang ada seperti: renovasi bangunan, pembuatan pagar keliling, pengadaan parker motot, renovasi masjid/mushallah dan pengadaan sumur pompa.

Pengadaan sarana dan prasarana seperti dituliskan di atas merupakan salah satu progam pengembangan dan peningkatan madrasah. Pengadaan sarana dan prasana tersebut terjadi pada tahun 2007 dengan menggunakan dana pemerintah dan juga donasi dari para alumni.

\section{Peran Madrasah Aliyah Negeri Palopo}

a. Bidang Pendidikan dan Keagamaan Peranan Madrasah Aliyah Negeri Palopo dalam bidang keagamaan diwujudkan dalam penanaman akhlakul karimah, media sosialisasi keislaman dan benteng moralitas peserta didik. Peran penting selanjutnya diwujudkan dengan adanya usaha lebih untuk meningkatkan dan memelihara kelangsungan tradisi Islam. Salah satunya yaitu melakukan kegiatan safari dakwah terutama ketika bulan Ramadhan. Kegiatan tersebut bertujuan untuk meningkatkan amal ibadah dan mencetak da'i-da'i yang mempunyai kemampuan berdakwah. Peserta didik yang mempunyai banyak ilmu pengetahuan mengenai agama Islam diberikan kesempatan untuk berdakwah di masjidmasjid. Seperti yang dikatakan oleh Bapak Haeruddin bahwa:

"Setiap bulan Ramadhan peserta didik yang sudah cukup bagus pengetahuannya tentang agama diikutkan di masjid-masjid untuk berdakwah guna untuk melatih mereka menjadi calon-calon da'i yang yang dapat bermanfaat bagi masyarakat kelak". (Haeruddin, 2019)

Kegiatan tersebut bukan sebagai ajang lomba, melainkan sebagai suatu kegiatan yang melatih peserta didik untuk mengembangkan kemampuan berdakwah dan mensyi'arkan agama Islam. Alumni dari Madrasah Aliyah Negeri Palopo yang sering melakukan kegiatan berdakwah dari masjid ke masjid seperti Ustadz Zulkifli yang kini juga membina anak-anak TPA di Walenrang dengan melakukan pelatihan dakwah.

\section{b. Bidang Sosial}

Keberadaan madrasah dalam suatu lingkungan masyarakat dapat menjadi wadah untuk beradaptasi dengan masyarakat setempat. Sehingga dapat tercipta hubungan yang baik antara masyarakat setempat dengan orang-orang yang ada dalam madrasah.

Dampak lain dari adanya Madrasah Aliyah Negeri Palopo bagi masyarakat sekitar yakni, menyadarkan orang tua bahwa belajar di sekolah berbasis agama seperti madrasah bukanlah hal yang membatasi pengetahuan siswa akan hal agama saja namun juga di madrasah tetap diajarkan pengetahuan umum yang dapat memberikan wawasan yang lebih luas lagi bagi siswa. Di madrasah Aliyah Negeri Palopo sendiri tidak hanya mengacu pada sistem pendidikan dari Kementrian Agama tetapi juga mengacu pada sistem pendidikan dari dinas pendidikan itu sendiri.

Hal di atas seperti yang dikemukakan oleh Bapak Abd. Majid bahwa:

"Para orang tua sudah mulai sadar dan banyak memasukkan anaknya ke 
madrasah sebab mereka sudah melihat bahwa ternyata madrasah juga mampu mencetak peserta didik yang memiliki prestasi sesuai dengan apa yang diharapkan oleh kebanyakan masyarakat di luar sana". (Majid, 2019)

Contohnya seperti guru-guru yang sekarang mengajar di Madrasah Aliyah Negeri Palopo, kebanyakan dari mereka sendiri merupakan alumni dari Madrasah Aliyah Negeri Palopo itu sendiri seperti Ibu Sitti Nun Ainun Yahya guru mata pelajaran akidah akhlak dan sejarah kebudayaan Islam dan juga Bapak Haenun yang telah menjadi kepala sekolah di MTs Batusitanduk. Adapun orang tua yang mulai memasukkan anaknya ke madrasah seperti ibu Ati yang telah menyekolahkan dua orang anaknya di Madrasah Aliyah Negeri Palopo dengan tujuan beliau ingin agar dalam diri anak-anaknya tertanam akhlak yang baik serta wawasan yang luas tidak hanya dari segi pengetahuan umum tetapi juga dari segi pengetahuan islami.

\section{E. Kesimpulan}

Madrasah Aliyah Negeri Palopo ini berdiri sebagai bentuk alihfungsi dari PGAN Palopo melalui beberapa tahapan pada tahun 1990 berdasarkan Surat Keputusan Menteri Agama RI, Nomor 64 Tahun 1990 pada tanggal 25 April 1990. Pada saat itu pula Madrasah Aliyah Negeri Palopo sebagai salah satu lembaga pendidikan formal yang dikelolah oleh Departemen Agama mulai dikembangkan sejalan dengan kebutuhan dan tuntutan masyarakat di Kota Palopo.

Selama rentang waktu dari tahun 1990 sampai akhir tahun 2007, dari PGAN Palopo lalu beralih fungsi menjadi MAN Palopo, telah mengalami beberapa kali pergantian Kepala Sekolah. Madrasah
Aliyah Negeri Palopo dari tahun 1990-2007 mengalami cukup banyak perkembangan di setiap fase kepemiminan kepala sekolah. Pada awal dialihfugsikannya dari PGAN menjadi MAN sudah memperlihatkan awal perkembangan yang baik pada masa kepemimpinan Bapak Drs. Abd. Latif P, B.A yang ditunjukkan dengan terciptanya suasana belajar yang baik dan meningkatnya kesejahteraan tenaga pendidik dan kedisiplinan yang terlihat baik dari beliau sendiri sampai kepada tenaga pendidik dan juga para peserta didik. Kemudian pada masa kepemimpinan kepala sekolah yang selanjutnya Madrasah Aliyah Negeri Palopo semakin berkembang dan mengalami peningkatan baik dari segi akademik maupun non akademik. Madrasaha Aliyah Negeri Palopo banyak mencetak prestasi dari segi akademik baik itu dalam bidang pendidikan umum maupun dalam bidang keagamaan. Dari segi non akademik dapat dilihat dengan adanya prestasi yang diraih pada kegiata-kegiatan ekstrakurikuler. Selain juga perkembangan yang lain juga dapat dilihat dari pembangunan fisik sekolah yaitu adanya renovasi gedung dan pembuatan fasilitas-fasilitas lainnya. Tidak hanya itu, dari segi non fisik juga dapat dilihat adanya pembinaan terhadap guruguru dan staf yang ada di sekolah.

Madrasah Aliyah Negeri Palopo merupakan madrasah yang keberadaan dan aktivitasnya sebagai lembaga pendidikan Islam yang mempunyai peran pendidikan sekaligus keagamaan yang penting dalam kehidupan masyarakat. Perannya dalam bidang pendidikan dan keagamaan seperti penanaman nilai-nilai keagamaan yang dapat membentuk kepribadian islami peserta didik dengan pondasi yang kuat melalui penanaman nilai- nilai keimanan dan memberikan Tsaqafah Islamiyah (wawasan islami) dan juga sebagai pengontrol dalam mengarungi era 
globalisasi. Dalam bidang sosial pun dapat dilihat perannya yaitu sebagai wadah untuk beradaptasi dengan masyarakat setempat.

\section{DAFTAR PUSTAKA}

Alawiyah , F., 2014. Pendidikan Madrasah di Indonesia. Aspirasi, 5(1).

Bustam, 2019. [Interview] (31 Juli 2019).

Haeruddin, 2019. [Interview] (1 Agustus 2019).

Hawa, M., 2019. [Interview] (31 Juli 2019).

Kosim, M., 2007. Madrasah di Indonesia (Pertumbuhan dan Perkembangan). 2(1).

Majid, A., 2019. [Interview] (1 Agustus 2019).

Nata, A., 2012. Sejarah Sosial Intelektual Islam dan Intitusi Pendidikannya. Jakarta: PT. Raja Grafindo.

Susanti, W., n.d. Pembinaan dan Pengembangan Madrasah Sampai Masa Sekarang. 